\title{
III Międzynarodowe Sympozjum Liturgiczne Ad fontes liturgicos (Preszów, 25-26 października 2012)
}

W dniach 25-26 października 2012 roku w Preszowie (Słowacja) odbyło się III Międzynarodowe Sympozjum Liturgiczne Ad fontes liturgicos nt. Ruch liturgiczny jako rezultat powrotu do źródeł liturgicznych. Organizatorami sympozjum były Greckokatolicki Wydział Teologiczny Uniwersytetu Preszowskiego, Ukraiński Katolicki Uniwersytet we Lwowie oraz Uniwersytet Papieski Jana Pawła II w Krakowie.

Sympozjum otwarł dziekan Greckokatolickiego Wydziału Teologicznego w Preszowie ks. prof. Peter Šturàk, który podkreślił wartość i znaczenie tej międzynarodowej współpracy naukowej. Uczestników sympozjum powitali także prorektor tego uniwersytetu doc. dr hab. Peter Adamišin oraz ks. Michal Onderko (w imieniu bpa Jana Babjaka SI).

Pierwszym prelegentem był ks. dr Janusz Mieczkowski z Krakowa, który przedstawił Początki ruchu liturgicznego w Europie Zachodniej. Ukazał on trzy koncepcje dotyczące początków tego ruchu: działalność Prospera Guérangera (1805-1875), Kongres w Malines w 1909 roku, gdzie Lambert Beauduin wygłosił referat na temat uczestnictwa wiernych w kulcie chrześcijańskim, oraz pierwszy „tydzień liturgiczny”, który odbył się w opactwie Maria Laach w 1914 roku.

Drugim referentem był ks. dr hab. Przemysław Nowakowski, prof. UPJPII, który przedstawił Przybliżenie wiernym źródeł liturgicznych jako główny cel polskiego ruchu liturgicznego i jego lidera ks. Michała Kordela z Krakowa. Po ukazaniu ośrodków polskiego ruchu liturgicznego (Lwów, Poznań, Gniezno, Sandomierz), prelegent skoncentrował się na działalności ks. Michała Kordela (1892-1936) w Krakowie. Podkreślone zostało jego nauczanie o liturgii i działalność pisarska w czasopiśmie „Mysterium Christi”.

Kolejny referat przygotowała s. dr hab. Adelajda Sielepin (Kraków) nt. Ruch liturgiczny $w$ Polsce i jego zadanie $w$ formowaniu duchowości liturgicznej. $Z$ powodu jej nieobecności, odczytał go ks. doc. Marcel Mojzeš z Preszowa. Autorka tekstu podkreśliła, że ruch liturgiczny, poprzez badania nad liturgią pierwszych wieków, miał na celu nawiązanie żywej relacji miedzy wiernymi a Chrystusem, który przychodzi do swojego ludu w liturgii.

Podsumowaniem pierwszego bloku referatów była dyskusja wokół roli badań źródeł liturgicznych w początkach ruchu liturgicznego. Badania te miały miejsce już wcześniej, jednak dopiero wykorzystanie ich do liturgii żywej w klasztorach i parafiach dało impuls do odnowienia liturgii. Uczestnicy zwrócili także uwagę na to, że u początków ruchu stali zakonnicy, choć bliżej ludu był przecież kler diecezjalny. Wynikało to z charyzmatu otrzymanego przez wybrane osoby. Uczestnicy zauważyli, że po Soborze pojawił się też tzw. „nowy ruch liturgiczny”, który domaga się powrotu do liturgii trydenckiej.

Drugi blok wykładów rozpoczął się od wystąpienia ks. dr hab. Erwina Matei z Opola, który przedstawił Ślaski ruch liturgiczny i jego wpływ na powrót duchowieństwa i wiernych do źródeł liturgicznych. Skoncentrował się on głównie na działalności ks. S. Stephana (1867-1926), który idee ruchu liturgicznego starał się zaszczepić na Śląsku. Rozpoczął 
on przekład łacińskich ksiąg liturgicznych, podkreślał znaczenie formacji liturgicznej oraz organizował kursy liturgiczne. Dążenia do odnowy liturgicznej podjęli także benedyktyni, którzy w roku 1919 przybyli do Krzeszowa.

Następnie głos zabrał ks. prof. dr hab. Vojtech Boháč (Preszów), który przedstawił Katechizm Kościoła Katolickiego z 1745 roku odnaleziony bibliotece Greckokatolickiego Wydziału Teologicznego $w$ Preszowie. Ten greckokatolicki katechizm był dziełem miejscowego biskupa. Opisywany szczegółowo przez prelegenta katechizm miał na celu ożywienie wiary wiernych w oparciu o zrozumienie świętej liturgii.

Jako trzeci w tej serii wystąpił Michal Glevaňák (Preszów) z referatem Dokumenty Soboru Watykańskiego II dotyczace problematyki przekładów tekstów liturgicznych i ich aplikacja w Kościele greckokatolickim po jego legalizacji w 1968 roku. Choć pierwsze próby przekładu na język słowacki Liturgii św. Jana Chryzostoma były podejmowane już wcześniej, to pełny przekład był możliwy dopiero po legalizacji Kościoła greckokatolickiego w Czechosłowacji (1968). Przyczyniły się do tego także dokumenty soborowe: konst. Sacrosanctum Concilium czy dekret Orientalium Ecclesiarum. Szczególną rolę w tym procesie odegrało czasopismo „Słowo”.

Dyskusja po tych referatach toczyła się wokół braku respektu dla prawa liturgicznego. To problem całego Kościoła, także greckokatolickiego. Kolejne pytania w dyskusji kierowane były do ks. prof. Vojtecha Boháča i dotyczyły podobieństw i rozbieżności obecnego katechizmu z tym z XVIII wieku.

Trzecią popołudniową sesję rozpoczął doc. dr Stefan Šak (Preszów) tematem Ruch duchowości a teologia Ojców Filokalistów - Kowalidowców w kontekście liturgicznej tradycji prawosławnej. Prelegent przypomniał dzieło ojców z Góry Atos - Filokalię, które po opublikowaniu w XVIII wieku wywarło ogromny wpływ na życie duchowe wiernych Cerkwi prawosławnej. Głównym przedmiotem ich nauczania była liturgia i życie sakramentalne.

Kolejnym referentem był dr Maksym Tymo z Lwowa. Przybliżył on słuchaczom Analize źródeł hymnografii bizantyjskiej jako klucza do odnowy i rozwoju liturgicznej modlitwy Kościoła. Na przykładach pochodzących z Pisma Świętego i liturgii wschodniej ukazał on metodę interpretacji źródeł bizantyjskich. Zwrócił uwagę na konieczność analizy nie tylko ich teologicznych korzeni, ale także zawartości, myśli autorów oraz zasad pisanej przez nich poezji.

Następny mówca ks. doc. dr Marcel Mojzeš z Preszowa przedstawił referat pt. Próba $z$ definiowania cech zdrowego ruchu liturgicznego. Prelegent sięgnął do doświadczeń ruchu liturgicznego w Kościele katolickim, prawosławnym oraz teologii Benedykta XVI. Prawdziwy ruch liturgiczny był przejściem Ducha Świętego przez Kościół. Nigdy nie był walką „przeciwko” komuś, ale był dążeniem „za” pewnymi wartościami. Przywrócił misterium paschalne do centrum liturgii i podkreślił prymat działalności Boga w liturgii.

Pierwsze pytania po trzeciej grupie referatów dotyczyły sprawy tłumaczeń tekstów liturgii na Ukrainie. Maksym Tymo podkreślił, że możliwe jest zupełnie nowe tłumaczenie tekstów, uwzględniające przedstawione przez niego w referacie postulaty. Dalsze rozważania dotyczyły ruchu liturgicznego. On się tak naprawdę nie skończył, więc ciągle musimy pogłębiać prawdziwego ducha soborowego. 
Pierwszy dzień sympozjum zakończył się pielgrzymką do greckokatolickiego sanktuarium św. Mikołaja w Lutinie, gdzie uczestnicy mogli sprawować lub uczestniczyć w liturgii św. Jana Chryzostoma.

Pierwsza sesja drugiego dnia sympozjum należała do naukowców z Lwowa. Otworzył ją referat dra Mychajło Petrowycza poświęcony Źródłom liturgicznej reformy kalendarza w rzymskich liturgicznych wydaniach „Recensio Ruthena” (1942). Autor zapoznał uczestników z okolicznościami prac nad tym kalendarzem, a także, opierając się na protokołach rzymskiej komisji liturgicznej, ukazał kryteria odnowy oraz liturgiczne i hagiograficzne źródła, z których korzystano podczas tej rewizji.

Doktor Wasyl Rudejko zaprezentował referat nt. Odnowy życia liturgicznego w Ukraińskim Kościele greckokatolickim wświetle powrotu do źródeł. Prelegent ukazał ten problem w wymiarze historycznym, zwracając uwagę na początki organizacji kultu, synod zamojski (1720), ruch liturgiczny, a także lata dziewięćdziesiąte XX wieku, kiedy to Kościół ten wyszedł z podziemia.

Następnie dr Igor Wasilišin zajął się Wspótczesnymi problemami porządku liturgicznego Kościoła obrzadku bizantyjskiego i perspektywami ich rozwiązania. Problemy te mają charakter zarówno ogólnokościelny, jak i regionalny (Ukraina, diecezja mukaczewska). Mówca ukazał je na przykładzie typikonu Izydora Dolnickiego oraz Aleksandra Mikity.

Temat ten kontynuowany był przez dra Augustyna Solanskijego, który przedstawił Specyfikę tradycji liturgicznej greckokatolickiej Diecezji Mukaczewskiej i typikonu Aleksandra Mikitu oraz próbę ich odnowy $i$ adaptacji. Przy obecnej tendencji powrotu do źródeł pojawił się problem, do jakiej tradycji ma wrócić diecezja mukaczewska, gdyż liturgia na jej terenie kształtowała się niezależnie od sąsiednich diecezji. Odpowiedź referent znajduje w typikonie Aleksandra Mikity z 1855 roku.

Dyskusja po tej serii referatów dotyczyła specyfiki Grekokatolickiego Kościoła Ukraińskiego. Obecne prace nie mogą traktować powrotu do źródeł jako okazji do zwalczania wpływów łacińskich, rosyjskich czy węgierskich. Byłyby źle, gdyby do głosu doszły problemy narodowościowe, także w konstrukcji kalendarza. Obecnie prace na Ukrainie koncentrują się przede wszystkim na przekładzie na język ukraiński typikonu.

Po chwili przerwy rozpoczął się ostatni blok wykładów. Na jego wstępie archidiakon Nyiran Janos z Nyiregyhaza (Węgry) przedstawił informację na temat konferencji o katechumenacie w tradycji bizantyjskiej, która odbyła się w klasztorze Mariapócs (Węgry) w dniach 12-13 października 2012 roku.

Następnie odbył się „okrągły stół”. Jako pierwszy wypowiedział się dr Mychajło Petrowycz, który zaproponował, by do materiałów z poszczególnych sympozjów dołączane były krytyczne wydania źródeł. Ksiądz prof. Przemysław Nowakowski, dziękując za dobrą organizację, zaprosił wszystkich do Krakowa, gdzie w przyszłym roku odbędzie się czwarte sympozjum z serii Ad fontes liturgicos. Po konsultacjach temat został określony w formie pytania: Czy reformy liturgiczne sa naprawdę powrotem do źródet? Ksiądz prof. Vojtech Boháć zaproponował, by każdy z referatów zawierał w przyszłości więcej konkretnych odniesień do źródeł oraz by sympozja te mogły być realizowane co dwa lata.

Ostatni blok referatów rozpoczęła dr Monika Slodičkowa (Preszów), która przedstawiła Wychowawczy aspekt liturgii wżyciu i dziele bł. bp. Wasyla Hopka (1904-1976). Referat zawierał przede wszystkim analizę dzieła bpa Wasyla Hopka Christos v nas, które ukazało 
się w 1948 roku i wywarło ogromny wpływ na rzesze wiernych na Słowacji. Największą jego zasługą było ukazanie prawdziwego piękna liturgicznych tekstów.

Następny mówca lic. Miroslav Šimko (Preszów) ukazał Odnowę ikonografii w Kościele bizantyjskim na Słowacji po roku 1989. W pierwszej części ukazał pozytywne przykłady odnowy w parafiach (np. Cabov), by w drugiej zająć się problemem formacji szkół i grup „piszących" ikony na Słowacji.

Dr hab. Marek Rembierz (Katowice) w referacie: Liturgia Logosu jako „rozumna służba Boża”? Spór teologiczno-religioznawczy dotyczący rozumienia liturgii przedstawił liturgię w ujęciu kard. Ratzingera. Sprawowanie liturgii ma być „wstąpieniem w odwiecznie dokonującą się liturgię niebios”. Misteria chrześcijańskie są misteriami Logosu. Wykraczają poza ludzki rozum, ale nie wiodą w bezkształt odurzenia ani w rozpłynięcie się rozumu w bezrozumowo pojmowany kosmos, lecz prowadzą do Logosu. Najtrafniej jest określać liturgię jako „służbę Bożą odpowiadającą Logosowi”. Logos stworzenia, logos w człowieku i prawdziwy Logos, który stał się ciałem - Syn spotykają się właśnie tutaj.

Ostatnim referatem był Ideał księdza w dziełach Klemensa Aleksandryjskiego jako jedna z części powrotu ad fontes liturgicos zaprezentowany przez dra Stanisława Ciupkę (Bielsko-Biała). Prelegent przeniósł więc uczestników do przełomu II i III wieku, gdzie ideałem kapłana była osoba święta i dobrze znająca zasady wiary.

Sympozjum zakończyła krótka dyskusja na tematy związane ze współczesnymi problemami kościoła Greckokatolickiego na Słowacji.

Kraków

KS. JANUSZ MIECZKOWSKI 